Article

\title{
Comparison of properties of Al-Cu soldered and resistance welded joints
}

\author{
Andrzej Ambroziak ${ }^{1}$, Artur Lange ${ }^{1 *}$, Piotr Białucki ${ }^{1}$, Wiesław Derlukiewicz ${ }^{1}$, Eryk Szymczak ${ }^{1}$ \\ ${ }^{1}$ Wrocław University of Science and Technology, Poland \\ Prof. Andrzej Ambroziak; andrzej.ambroziak@pwr.edu.pl \\ Piotr Białucki, Ph.D.; piotr.bialucki@pwr.edu.pl \\ Wiesław Derlukiewicz, Ph.D.; wieslaw.derlukiewicz@pwr.edu.pl \\ Eryk Szymczak, M.Sc.; 229114@student.pwr.edu.pl \\ * Correspondence: Artur Lange, Ph.D.; artur.lange@pwr.edu.pl
}

Received: 10.12.2019; Accepted: 27.02.2020

\begin{abstract}
The paper presents the results of qualitative tests of $\mathrm{Cu}$ - $\mathrm{Al}$ joints made by soldering, brazing and resistance welding. Aluminum and copper tubes with a diameter of $6.9 \mathrm{~mm}$, used, among others in refrigeration systems, were soldered with ZnAl2 and AlSi12 filler metal. In addition, similar connections were made by resistance welding. Macroscopic tests of soldered and welded joints were carried out and the hardness distribution on the cross-section of joints was determined. The analysis of research results allowed to state that resistance welding of $\mathrm{Cu}-\mathrm{Al}$ joints can be a good alternative to the soldering process, especially in series production, due to the possibility of easy application of process mechanization.
\end{abstract}

Keywords: soldering; brazing; resistance welding; $\mathrm{Cu}-\mathrm{Al}$ joints

\section{Introduction}

The possibility of joining aluminum with copper by welding [1], braze welding using the TIG method

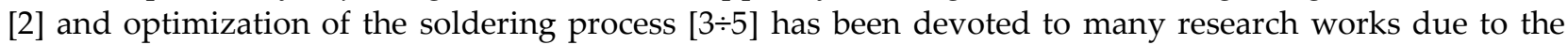
increasing use of dissimilar connections in industry.

Combining various metals is complicated by the fact that they often form intermetallic phases, which are usually characterized by high hardness and brittleness. There are hard and brittle $\mathrm{Cu}_{\mathrm{n}} \mathrm{Alm}$ type compounds in the aluminum-copper phase balance system [6]. The most important phases occurring in the two-component $\mathrm{Al}-\mathrm{Cu}$ system from the point of view of soldering and welding processes are hard intermetallic phases (phases in the range of $58-78 \%$ at. $\mathrm{Cu}$ ) that can arise during making connections [6,7]:

- $\theta-\mathrm{Al}_{2} \mathrm{Cu}(31,9 \div 33 \%$ at. $\mathrm{Cu})$;

- $\gamma_{1}-\mathrm{Al}_{4} \mathrm{Cu}(62,5 \div 69 \%$ at. $\mathrm{Cu})$;

- $\delta-\mathrm{Al}_{2} \mathrm{Cu}_{3}(59,3 \div 61,9 \%$ at. $\mathrm{Cu})$.

The presence of intermetallic phases in the joint structure reduces the strength properties of the joints and may lead to cracks in their operation. That is why the participation of intermetallic phases and their form in the connection is so important. Better properties are obtained when these phases are not large and occur in a dispersed form, and not in the form of clusters or a continuous coating at the grain boundaries. One of the ways to reduce the occurrence of intermetallic phases on the border between aluminum and other metals is to use appropriate diffusion barriers $[8,9] . \mathrm{Al}_{2} \mathrm{O}_{3}$

An additional difficulty of joining is the very high affinity of aluminum for oxygen, and the $\mathrm{Al}_{2} \mathrm{O}_{3}$ oxide formed on its surface occurs in the form of a tight and durable layer [10].

The basic problems associated with joining aluminum with copper are:

- choosing the appropriate flux or gaseous environment that ensures the removal of oxides from the surface of such a variety of materials,

- creating brittle connections through the formation of intermetallic phases in the soldered joint, taking into account additional alloying elements found in the solder,

- a large difference in the chemical and physical properties of aluminum and copper.

The purpose of the work was to compare the properties of aluminum-copper pipe joints made by welding and soldering (using variable soldering binders), which find their application in industry as joints ensuring proper tightness.

Soldering is more used to make Al-Cu joints during assembly and to make such joints outside the production line or in small-lot production, while welding is used in mass production. 
Identification of the occurring phases requires an analysis using the X-ray diffraction method, which is expensive under production conditions and was not the subject of the work, while hardness measurements can be a preliminary verification of the form of intermetallic phases.

\section{Soldering of Al-Cu joints}

Flame soldering (propane oxygen) and resistance butt welding were used to make $\mathrm{Al}-\mathrm{Cu}$ joints. Soldering was performed using zinc and aluminum binders, whose chemical composition is shown in table I.

The paper presents the results of tests on $\mathrm{Al}-\mathrm{Cu}$ connections made of pipes with a diameter of $\varnothing 6.9 \times 0.8 \mathrm{~mm}$ made of $\mathrm{Al}-1070 \mathrm{~A}$ aluminum and $\mathrm{Cu}-\mathrm{DHP}$ copper.

The following additional materials for soldering were used in the tests:

- CASTOLIN 192 FX flux;

- CASTOLIN Thinner 190AL flux fluid;

- binder - L-ZnAl2 in the form of a solid wire $ø 1,6 \mathrm{~mm}$ (trade name CASTOLIN EcoBraz 38502T);

- binder -L-AlSi12 ø1.6 mm cored wire, designation according to PN-EN ISO 17672 [5].

The used additional materials are used both for soldering similar joints with aluminum and soldering dissimilar joints with aluminum and copper. The chemical composition and melting point of the binders used are shown in table I.

Table I. Chemical composition and melting point of binders

\begin{tabular}{cccccc}
\hline Binder & \multicolumn{3}{c}{ Wt.\% content } & & $\begin{array}{c}\text { Melting } \\
\text { temperature } \\
\end{array}$ \\
& Zn & Al & Si & ${ }^{\circ}$ C \\
\hline L-AlSi12 & - & rest & 12 & $575 \div 585$ \\
EcoBraz 38502T (L-ZnAl2) & rest & $1.5 \div 4.5$ & - & $377 \div 410$ \\
\hline
\end{tabular}

The studies used socket joints with a socket length of $12 \mathrm{~mm}$. The design of the soldered joint is shown in figure 1. The size of the gap in the soldered joint at soldering temperature was about $0.084 \mathrm{~mm}$ in the joint with the socket in the aluminum tube, and about $0.065 \mathrm{~mm}$ in the joint with the socket in the copper tube, therefore both gaps should have high capillary properties. The types of soldered joints samples and additional materials used are presented in table II.

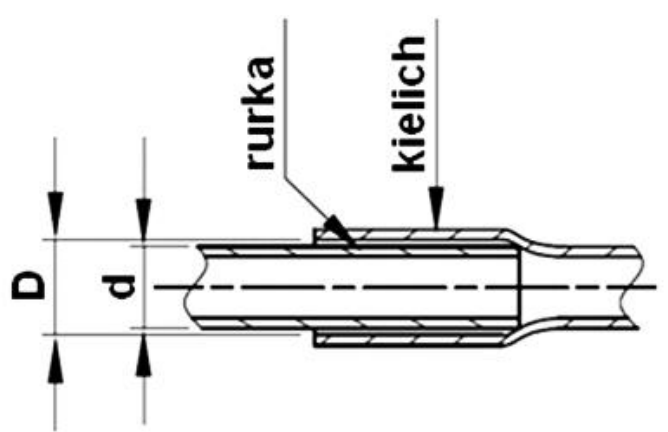

Fig. 1. Design of the socket joint of Al-Cu pipes

Table II. Types of soldered joints used in tests

\begin{tabular}{|c|c|c|c|c|c|c|c|c|c|}
\hline \multirow{2}{*}{$\begin{array}{c}\text { Series } \\
\text { Joint No. }\end{array}$} & \multicolumn{3}{|c|}{1} & \multicolumn{2}{|c|}{2} & 3 & \multicolumn{2}{|c|}{4} & 5 \\
\hline & 1.1 & 1.2 & 1.3 & 2.1 & 2.2 & 3 & 4.1 & 4.2 & 5 \\
\hline Flux & $192 \mathrm{FX}$ & $192 \mathrm{FX}$ & $192 \mathrm{FX}$ & $192 \mathrm{FX}$ & $192 \mathrm{FX}$ & $\begin{array}{l}\text { In the } \\
\text { wire }\end{array}$ & $\begin{array}{l}\text { In the } \\
\text { wire }\end{array}$ & $\begin{array}{l}\text { In the } \\
\text { wire }\end{array}$ & $\begin{array}{l}\text { In the } \\
\text { wire }\end{array}$ \\
\hline Binder & $\mathrm{ZnAl2}$ & $\mathrm{ZnAl} 2$ & $\mathrm{ZnAl2}$ & $\mathrm{ZnAl} 2$ & ZnAl2 & AlSi12 & AlSi12 & AlSi12 & AlSi12 \\
\hline Solder form & Wire & Wire & Wire & Ring & Ring & Wire & Wire & Wire & Wire \\
\hline Pipe & $\mathrm{Cu}$ & $\mathrm{Cu}$ & $\mathrm{Cu}$ & $\mathrm{Al}$ & $\mathrm{Al}$ & $\mathrm{Cu}$ & $\mathrm{Al}$ & $\mathrm{Al}$ & $\mathrm{Cu}$ \\
\hline Socket & $\mathrm{Al}$ & $\mathrm{Al}$ & $\mathrm{Al}$ & $\mathrm{Cu}$ & $\mathrm{Cu}$ & $\mathrm{Al}$ & $\mathrm{Cu}$ & $\mathrm{Cu}$ & $\mathrm{Al}$ \\
\hline
\end{tabular}


The basic type of joint was made with a socket in an aluminum tube. To compare soldering properties, soldering tests were also carried out on joints with a copper pipe socket. View of the joints of pipes prepared for soldering is shown in figure 2.

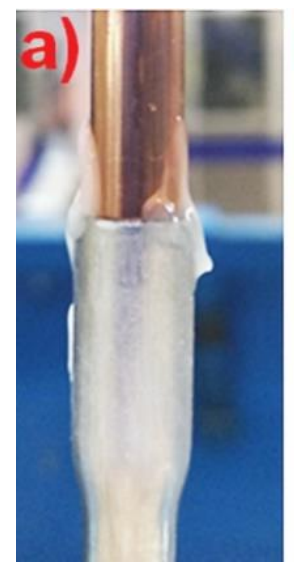

(a)

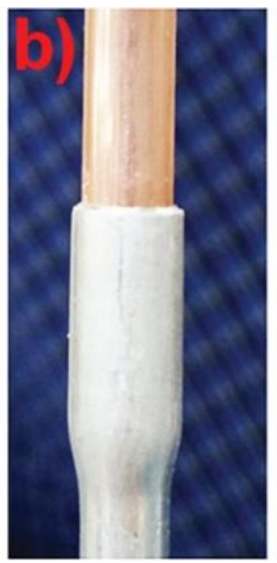

(b)

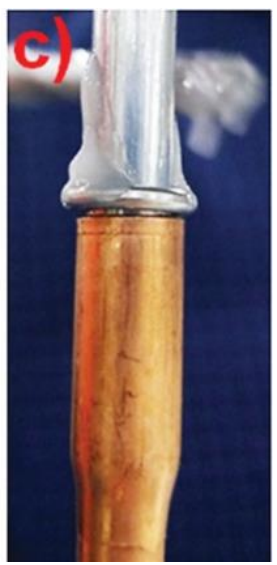

(c)

Fig. 2. View of the joints of samples for soldering using different forms of binder: a) flux and binder in wire separately, b) core wire with flux in the center, c) flux and ring binder separately

During soldering, the flame was directed mainly at the copper tube. After soldering, all joints had excess solder on the outer surface of the socket. View of joints after soldering and cleaning the surface of flux residue is shown in figure 3.

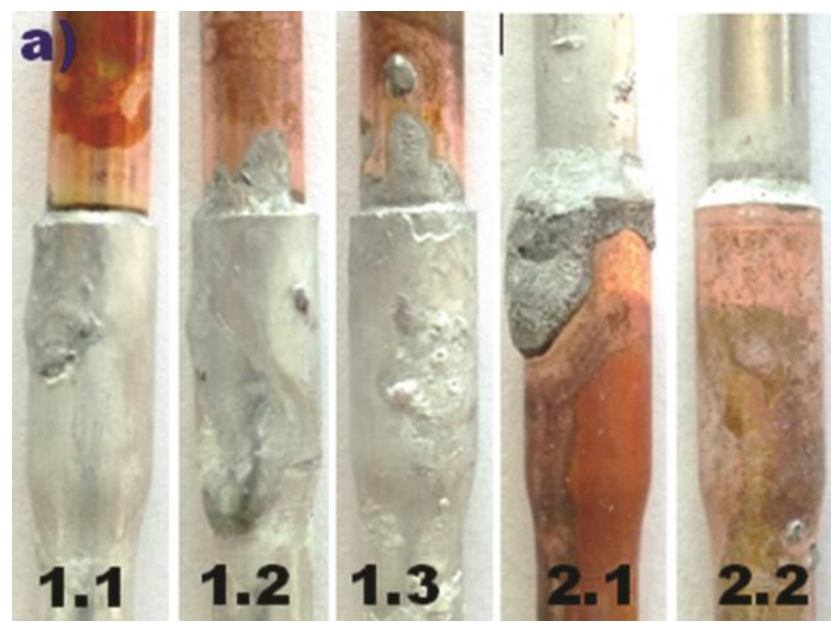

(a)
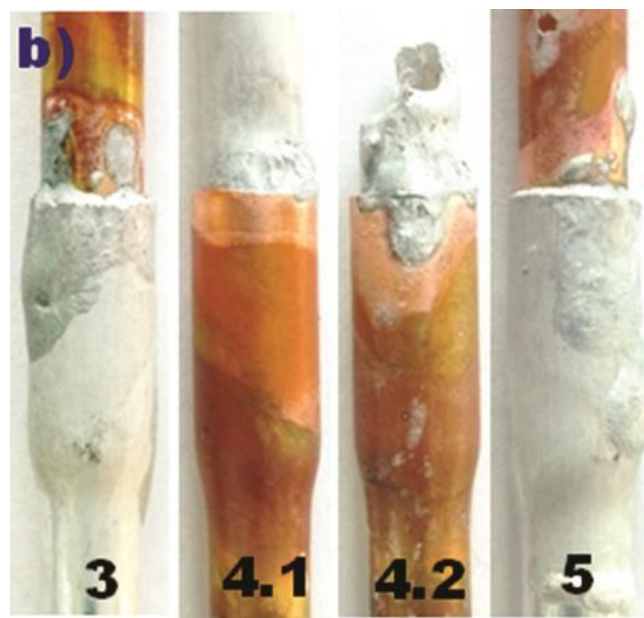

(b)

Fig. 3. View of joints after soldering and cleaning of excess flux. Joint numbers according to designations of the samples given in Table 2; a) ZnAl2 solder joints, b) AlSi12 solder joints

As can be seen in figure 3, a large amount of binder remained on the socket, which did not flow into the capillary gap between the $\mathrm{Al}$ and $\mathrm{Cu}$ pipes. The damage to the aluminum tube visible in connector 4.2 was the result of excessive heating. The slight difference in melting temperatures of L-AlSi12 solder $\left(575 \div 585{ }^{\circ} \mathrm{C}\right)$ and aluminum $\left(660^{\circ} \mathrm{C}\right)$ requires very precise heat input to the joint, which can be difficult even for an experienced solder.

Macrostructural tests of soldered joints (Fig. 4) with AlZn2 solder showed good filling over the entire length of the overlap, while differences in the quality of filling the gap around the perimeter of the tube are visible in joints soldered with AlSi12. Connections 4.1, 4.2 and 5 made of AlSi12 solder show that the required minimum fill length of $4 \mathrm{~mm}$ [11] for tight joints is also possible with aluminum solder.

\section{Welding of Al-Cu joints}

For resistance welded joints, samples were prepared in accordance with figure 5. In this case, only the outer tube system made of aluminum was used, the inner tube was copper. The tubes used for welding were in the same delivery condition as the tubes used for soldering. 

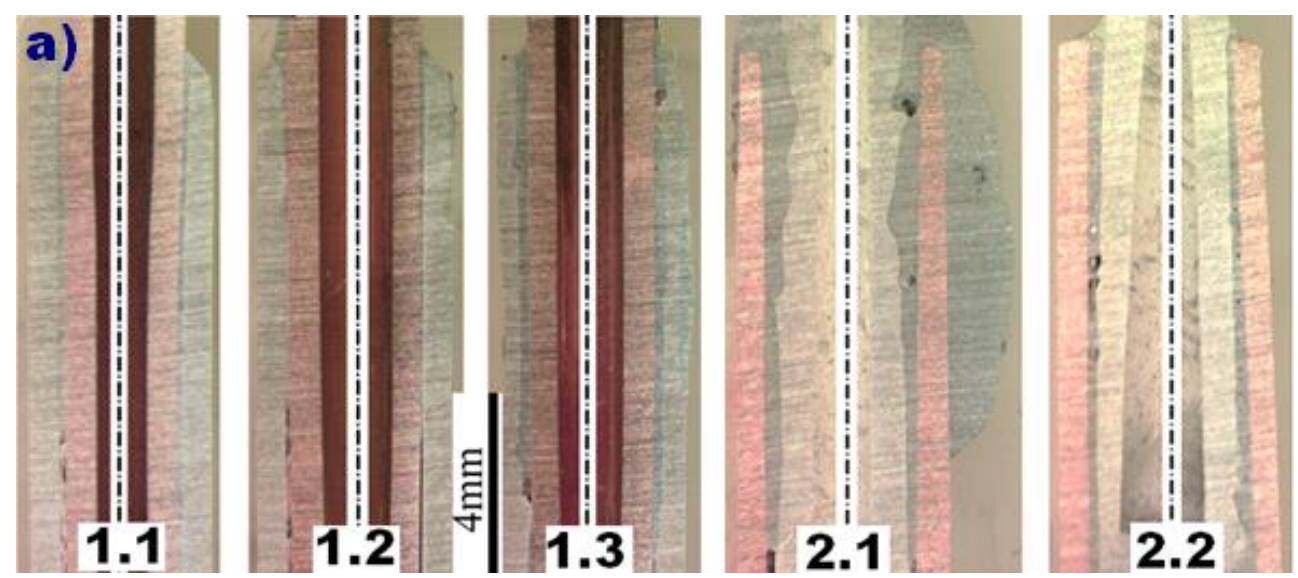

(a)
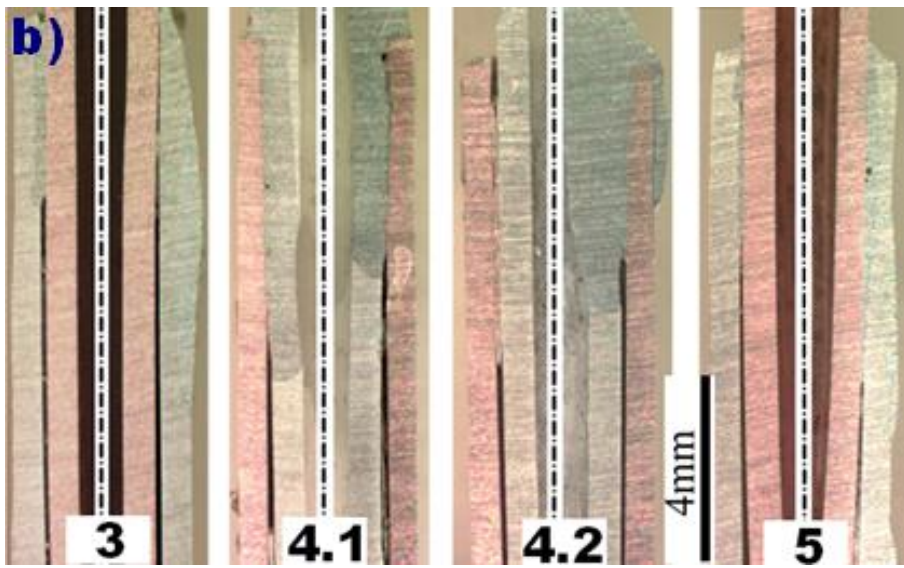

(b)

Fig. 4. Macrostructure of soldered $\mathrm{Cu}-\mathrm{Al}$ joints: a) joints No. $1.1 \div 2.2$ soldered with zinc solder; b) joints No. $3 \div 5$ soldered with aluminum solder

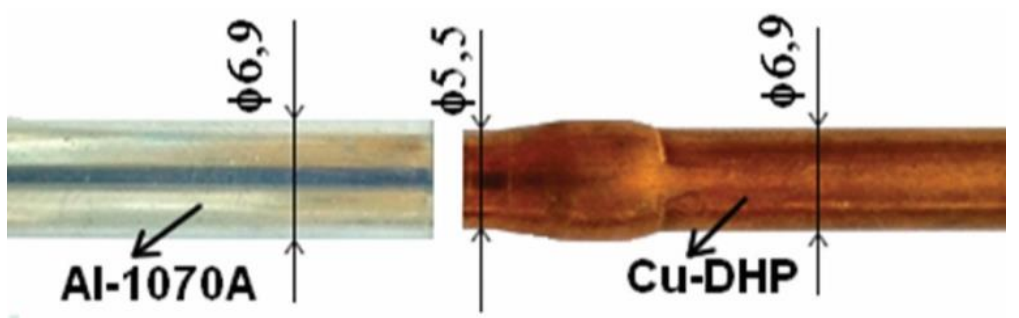

Fig. 5. Preparation of pipes for short-circuit resistance welding

During welding, the aluminum tube on the inner surface undergoes partial melting, and during upsetting in the final pressure of the welding process, the liquid metal is pushed out of the joint. View of Al-Cu resistance welded joints is shown in figure 6, and the macrostructure in figure 7.

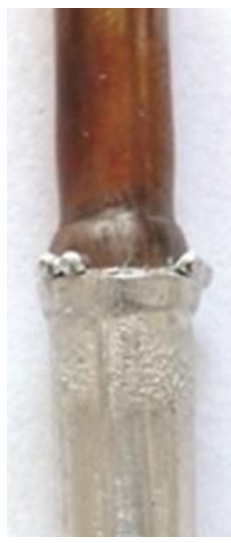

(a)

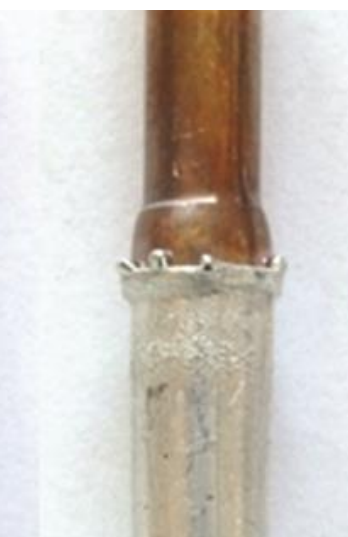

(b)

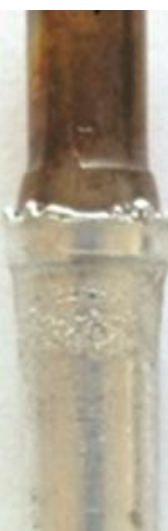

(c)

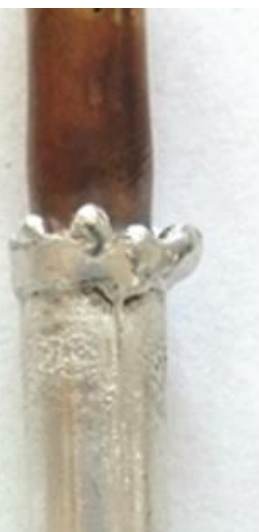

(d)

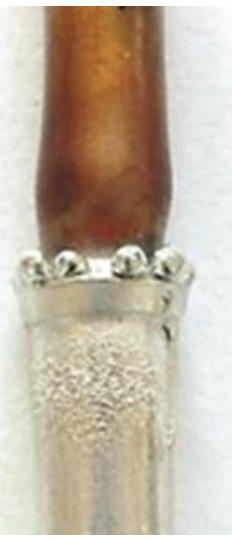

(e)

Fig. 6. View of Al-Cu resistance welded joints 
The criteria for the correctness of making the joint are ensuring the tightness of the connection and the formation of a weld over a length of at least $2 \div 3 \mathrm{~mm}$ (in industrial conditions). As can be seen in figure 7 , all joints meet this condition, the connection (solder) length is $\mathrm{min} .4 \mathrm{~mm}$.

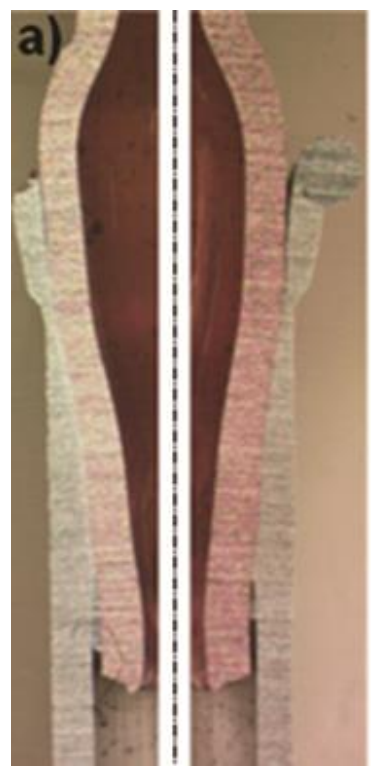

(a)

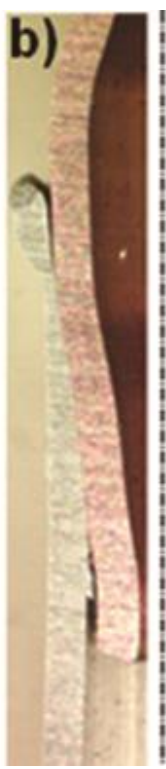

(b)

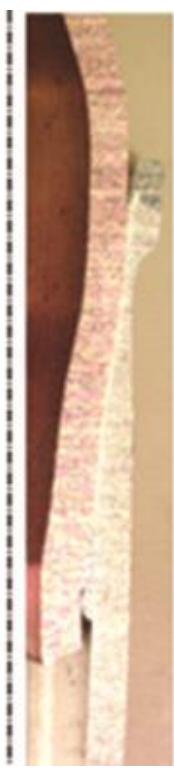

)

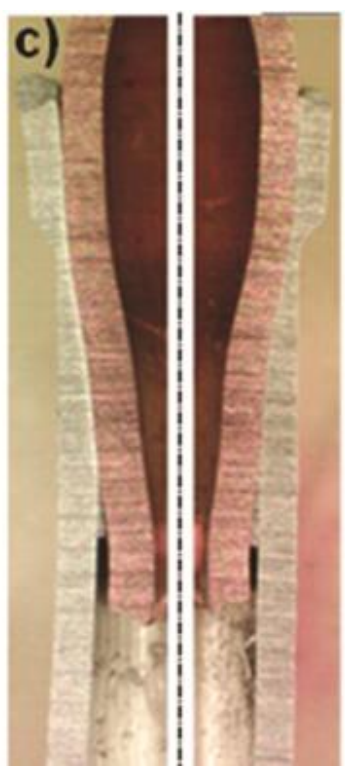

(c)

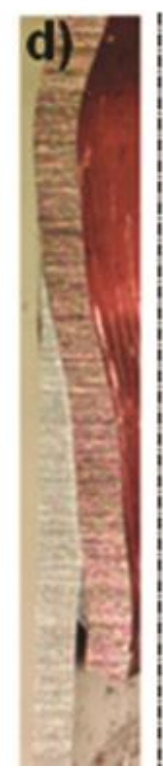

(d)

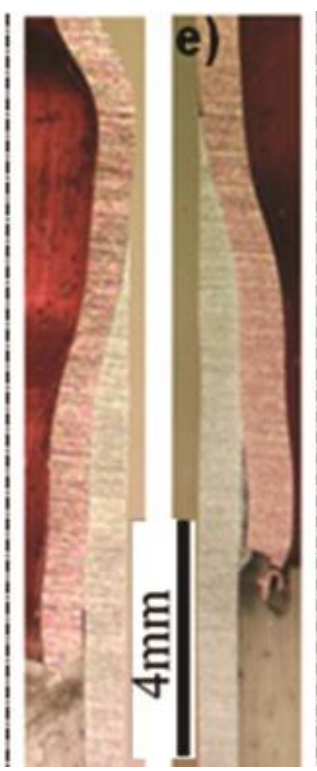

(e)

Fig. 7. Macrostructure of $\mathrm{Al}-\mathrm{Cu}$ resistance welded joints

\section{Microscopic examinations}

Comparing the structure of soldered and welded joints, it can be seen that in soldered joints there are areas marked as: $\mathrm{Al}, \mathrm{Al}-\mathrm{L}, \mathrm{L}, \mathrm{L}-\mathrm{Cu}, \mathrm{Cu}$ (Fig. 8a), while in welded joints there are areas of $\mathrm{Al}, \mathrm{Al}-\mathrm{Cu}, \mathrm{Cu}$ (Fig. 8b). In soldered joints there is a large number of gas bubbles and clear erosion (dissolution of the native material) from the side of the aluminum tube (Figs. 8 and 9). In the welded joints on the welding line a narrow partial melting zone is visible.

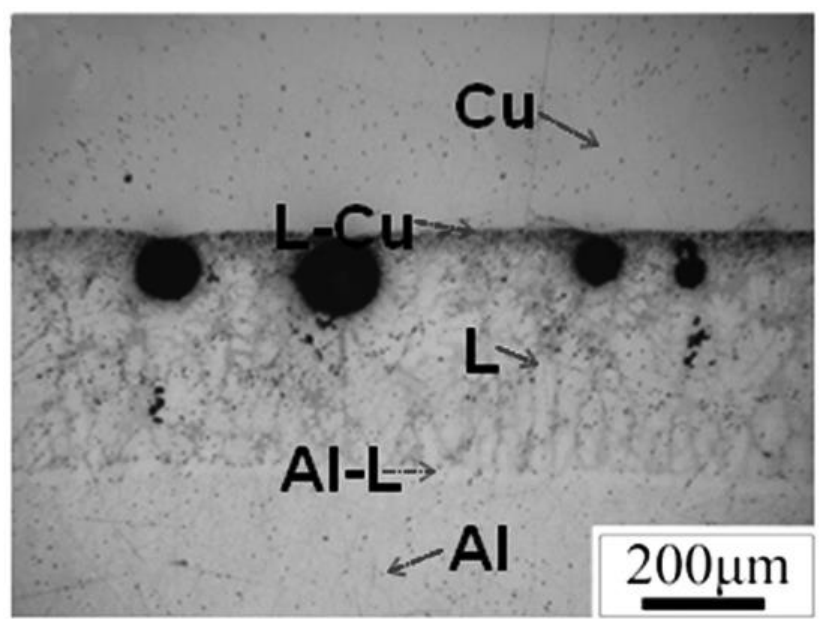

(a)

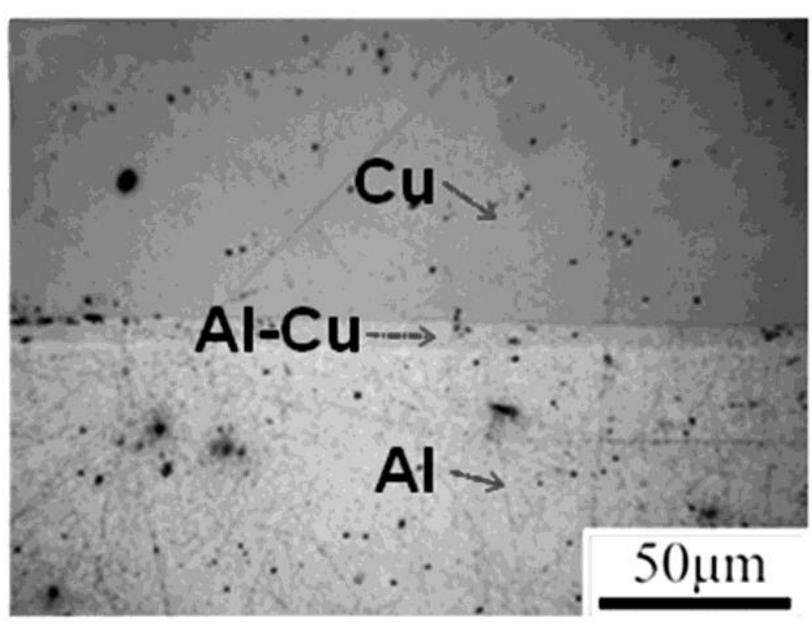

(b)

Fig. 8. Macrostructure of AL-Cu soldered and resistance welded joints: a) solder joint, Al-aluminum material, Al-L solder and aluminum diffusion zone, L-zinc solder, L-Cu-solder and copper diffusion zone, Cu-copper material; b) Al-aluminum material, $\mathrm{AL}-\mathrm{Cu}$ - phases formed from aluminum and copper, $\mathrm{Cu}$-copper material

\section{Hardness measurements}

The hardness of soldered and welded joints was measured by the Vickers method at a load of $0.098 \mathrm{~N}$. The distribution of hardness measuring points in soldered and welded joints is shown in figure 9, while the measurement results are shown in figures 10 and 11. 


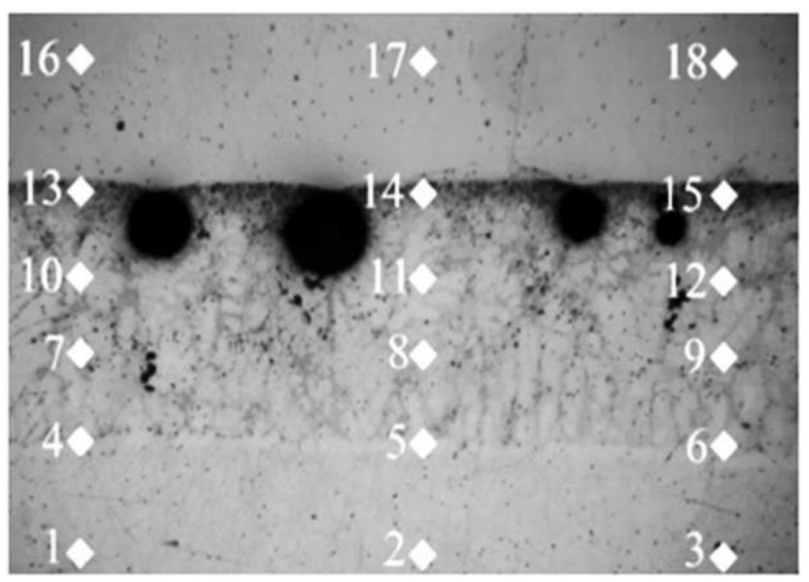

(a)

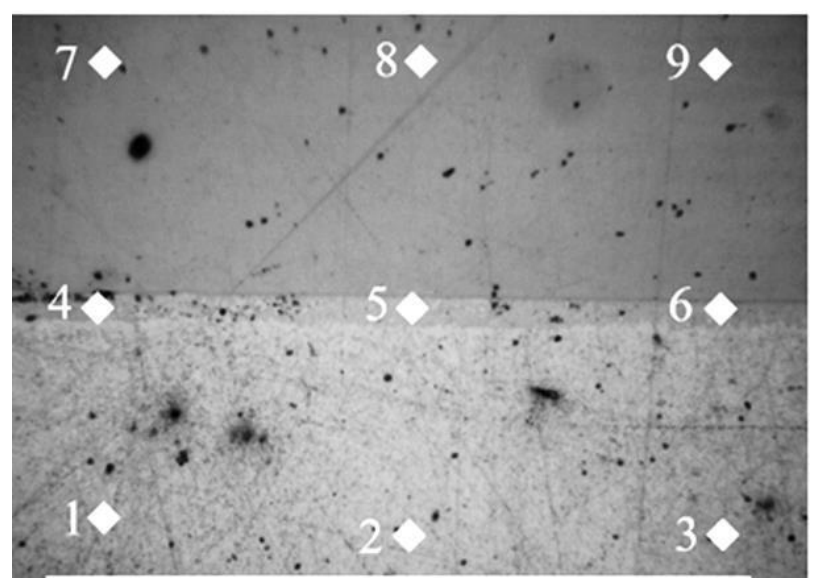

(b)

Fig. 9. Arrangement of hardness measurement points in: a) solder joints, b) resistance welded joints

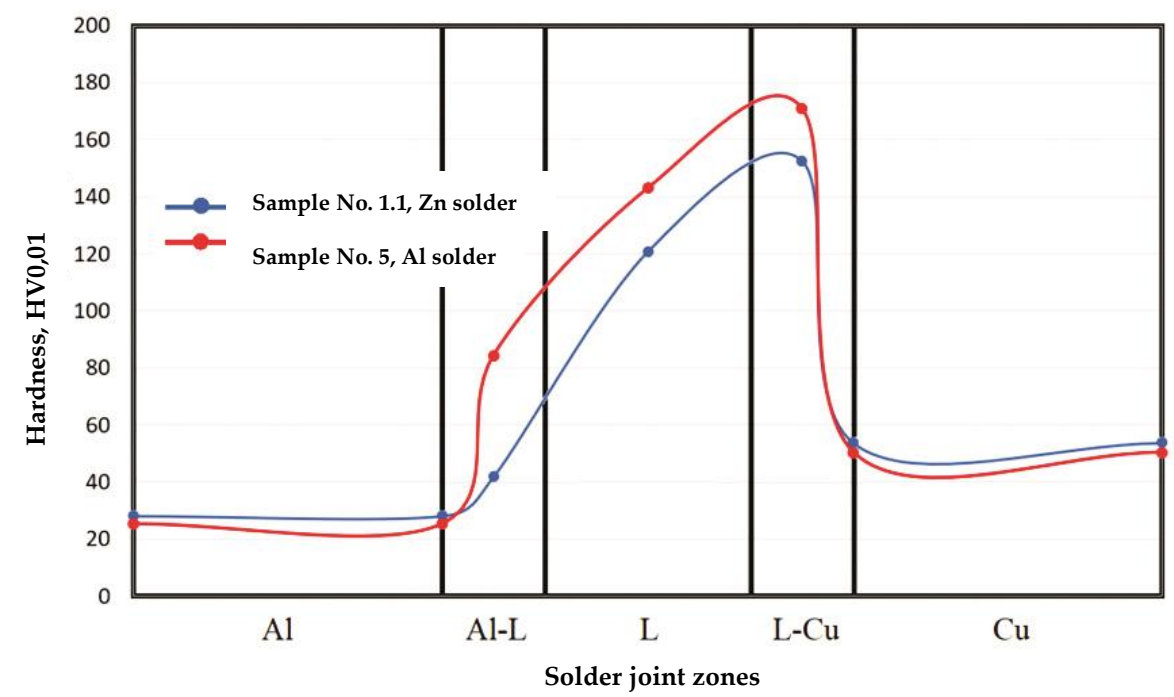

Fig. 10. Distribution of $\mathrm{HV} 0,1$ hardness in $\mathrm{Cu}-\mathrm{Al}$ soldered joints

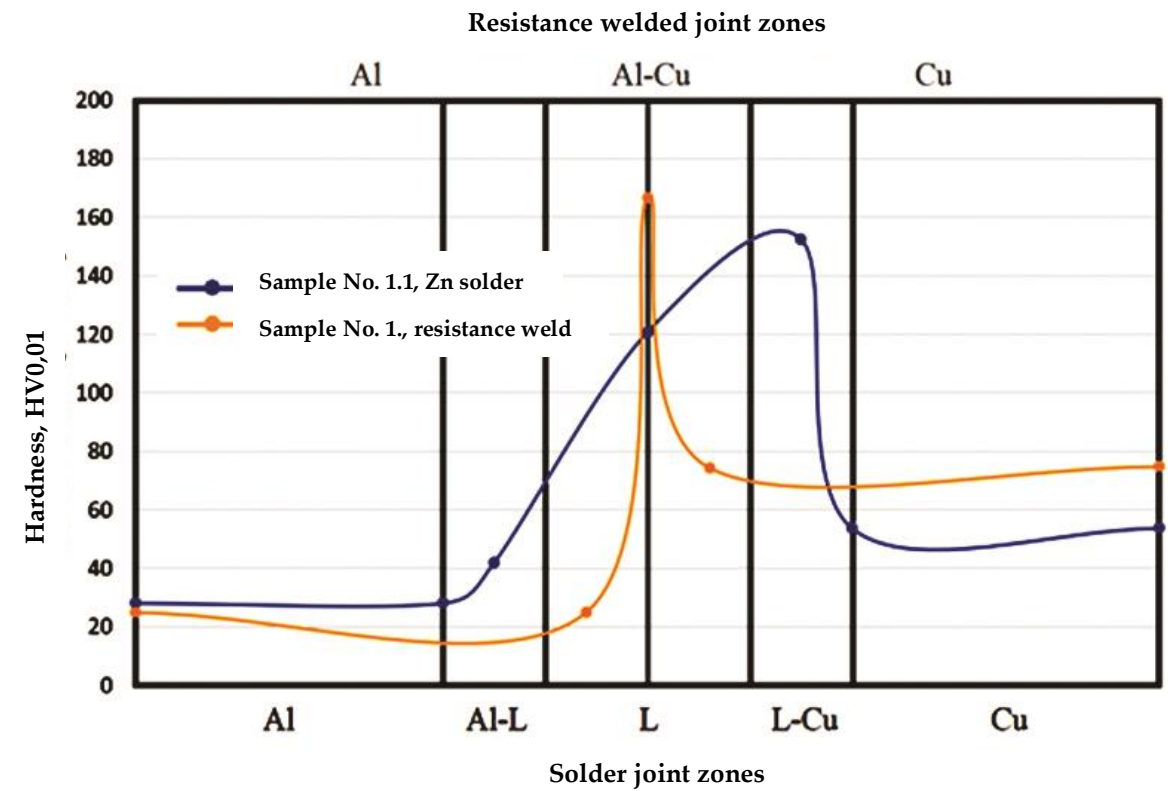

Fig. 11. Distribution of HV0.1 hardness in $\mathrm{Cu}-\mathrm{Al}$ soldered and resistance welded joints

Hardness measurements were aimed at determining whether in the connection area both in the soldering process and in the welding process there are no hard and brittle intermetallic phases that can be observed in the Al-Cu equilibrium system causing a significant reduction in the operational properties of the connections [12]. During the operation of the compressor aggregate, due to the occurring vibrations, 
micro-cracks may appear between the matrix and non-coherent precipitations of the Al2Cu metallic phase, which during long-term operation lead to cracks.

Hardness measurements show that in both soldered and welded joints there is an increase in hardness compared to the hardness of native copper and aluminum materials. In the soldered joint this increase occurs in the copper diffusion area, while in the welded joint on the aluminum and copper melting line. As demonstrated in $[13,14]$, the reason for the increase in hardness are the intermetallic phases of aluminum and copper formed in soldered and welded joints, and as you can presume the consequence of their presence is usually a reduction in mechanical properties [15].

\section{Conclusions}

1. The use of ZnAl2 zinc binder for soldering the $\mathrm{Al}-\mathrm{Cu}$ pipe connection allows to obtain a solder connection with better parameters (length of formed solder) and quality (fewer pores in the solder and bubbles than in joints made with AlSi12 solder).

2. The main problems occurring when making soldered joints are: limited wetting of copper surface by liquid solder, formation of hard and brittle intermetallic phases and ease of overheating (partial melting) of the aluminum tube.

3. The main disadvantage of welded joints is the presence of hard and brittle intermetallic phases in the Al-Cu transition zone, which cause a step change in hardness in the joint. The consequence of these phases is usually a reduction in the mechanical properties. Avoiding the formation of these phases is difficult because the said structure is formed during the welding process and its production is necessary for the proper formation of the weld and cleaning of the adjacent copper and aluminum surfaces, therefore solder joints are more favorable from the point of view of operational properties.

4. The quality of solder joints made by flame soldering is strongly related to the skills of the solder. Obtaining perfect repeatability of the connection process is not possible. The method has limited application in mass production because it is difficult to automate and increase the speed of making connections.

5. The use of soldering is recommended for making Al-Cu joints during assembly and making such connections off the production line due to the ease of application of this method regardless of the conditions, position of soldering and complexity of the connection.

6. Welded joints made in a semi-automatic process are characterized by greater repeatability of the process and the quality of the joints obtained. The nature of the process also allows its full automation and application in mass production.

Author Contributions: conceptualization A.L. and A.A.; methodology P.B, A.L.; validation A.L, P.B.; formal analysis A.L, P.B.; investigation A.L, P.B., W.D., E.S.; data curation A.L., P.B.,E.S.; writing-original draft preparation A.L., P.B.; writing-review and editing A.A., A.L.; visualization P.B, A.L.; supervision A.A.;

Funding: The research was financed from the statutory fund of Wrocław University of Science and Technology.

Conflicts of Interest: The authors declare no conflict of interest.

\section{References}

[1] Papkala H., Pietras A., Zgrzewanie Aluminium z miedzia, Biuletyn Instytutu Spawalnictwa, 2005, Vol. 49(4), 30-41.

[2] He H., Wu C., Lin S., Yang C., Pulsed TIG Welding-Brazing of Aluminum-Stainless Steel with an Al-Cu Twin Hot Wire, Journal of Materials Engineering and Performance, 2019, Vol. 28(2), 1180-1189. https://doi.org/10.1007/s11665-018-3848-y

[3] Szymczak E., Comparison of properties of soldered and welded Cu-Al joints, M.Sc. diploma, Wrocław University of Science and Technology, Poland, 2018.

[4] Ambroziak A., Lange A., Derlukiewicz W., Mosińska S., Aluminium and aluminium alloy hard soldering technology, Welding International, 2012, Vol. 26(5), 330-334. https://doi.org/10.1080/09507116.2011.581339

[5] Ambroziak A., Lange A., Examination of microstructure of Al-Cu joints with AlCu20Ag36 solder, Welding Technology Review, 2004, Vol. 76(8/9), 86-88.

[6] Murray J.L., Binary Alloy Phase diagrams, ASM international Material Park, OH 1992 Vol. 5.

[7] Xia C., Li Y., Puchkov U.A., Gerasimov S.A., Wang J., Microstructure and phase constitution near the interface of $\mathrm{Cu} / \mathrm{Al}$ vacuum brazing using Al-Si filler metal, Vacuum, 2008, Vol.82(8), 799-804. 
https://doi.org/10.1016/j.vacuum.2007.11.007

[8] Mirski Z., Wojdat T., Połączenia lutowane aluminium z miedzią, stalą niestopową i stopowa, wykonane spoiwami cynkowymi, Welding Technology Review, 2013, Vol. 85(2), 2-8. https://doi.org/10.26628/ps.v85i4.260

[9] Lange A., Investigation of brazing filler to aluminum-copper joints. Ph.D. thesis, Wrocław University of Science and Technology, Poland, 2002.

[10] Winiowski A., Application of diffusion soldering for joining metals and alloys (in Polish), Welding Technology Review, 1999, Vol. 71(4).

[11] Radomski T., Ciszewski A., Brazing, WNT, Warszawa 1985.

[12] ISO 17672:2010(E) - Brazing - Filler metals.

[13] JI Feng, XUE Song-bai, LOU Ji-yuan, LOU Yin-bin, WANG Shui-qing, Microstructure and properties of $\mathrm{Cu} / \mathrm{Al}$ joints brazed with ZnAl filler metals, Transactions of Nonferrous Metals Society of China, 2012, 22, $281-287$. https://doi.org/10.1016/S1003-6326(11)61172-2

[14] Marya M., Marya S., Interfacial microstructures and temperatures in aluminium-copper electromagnetic pulse welds, Science and Technology of Welding and Joining, 2004, Vol. 9(6), 541-547. https://doi.org/10.1179/174329304X8685

[15] Xianglong Zhou, Gang Zhang, Yu Shi, Ming Zhu, Fuqian Yang, Microstructures and mechanical behavior of aluminum-copper lap joints, Materials Science, 2017, 105-113. https://doi.org/10.1016/j.msea.2017.08.056

(C) 2020 by the authors. Submitted for possible open access publication under the terms and conditions of the Creative Commons Attribution (CC BY) license (http://creativecommons.org/licenses/by/4.0/). 